\title{
Kajian Nilai dan Konsep Pengobatan Tradisional Pada Lontar Usada Yeh
}

\author{
Asthadi Mahendra Bhandesa ${ }^{1}$, Nadya Treesna Wulansari ${ }^{2}$, I Putu Agus Endra Susanta ${ }^{3}$ \\ ${ }^{123}$ Institut Teknologi dan Kesehatan Bali \\ 1asthadi.88@gmail.com.2nadyatreesna@gmail.com. ${ }_{2}^{3}$ ramaendra@gmail.com
}

\begin{abstract}
Abstracs
Usada yeh is essentially a usada lontar that contains the types of diseases, methods of treatment using water and mantras, and various other upakara facilities. In Usada yeh, the composition and order of the dasaksara were known as the primary basis for using the usada treatment. The purpose of this study was to analyze the value and concept of traditional medicine in usada yeh lontar. This study was employed descriptive qualitatively using an ethnomedicine approach. The data were analyzed through content analysis of lontar usada yeh and in-depth interviews with a pangusadha and academics in Hinduism. The finding indicated that: The values contained was the value of theological education in the form of the teachings of divinity and worship of Tri Purusa (Parama Shiva, Sada Shiva, and Shiva), and the value of health education, such as knowledge about various diseases, treatment methods, knowledge of usada mantram and means based on Shivaistic concepts through tantric teachings. The concept of usada yeh traditional medicine was based on an understanding of the composition and sequence of dasaaksara, in the form of treatment for all kinds of diseases using several means, namely water, mantram, drops, herbal medicine, spray, powder, usug, sesayut, caru, daksina, and other rituals. Moreover, usada yeh could be implemented by combining any type of wood tree. In conclusion, the values and concepts of traditional medicine in lontar usada yeh are centered on water, mantram and ingredients made from natural ingredients and other rituals.
\end{abstract}

Keywords: Value; Traditional Medicine; Usada Yeh; Lontar

\begin{abstract}
Abstrak
Usada yeh pada hakekatnya merupakan lontar usada yang memuat tentang jenis penyakit, cara pengobatan menggunakan air dan mantram serta berbagai sarana upakara lainnya, dalam usada yeh disebutkan mengetahui susunan serta urutan dari dasaksara sebagai dasar utama menggunakan pengobatan usada tersebut. Penelitian ini bertujuan untuk menganalisis nilai dan konsep pengobatan tradisional pada lontar usada yeh. Metode yang digunakan adalah deskriptif kualitatif dengan menggunakan pendekatan etnomedisin, analisis data dilakukan melalui analisis isi lontar usada yeh dan wawancara mendalam dengan seorang pangusadha dan akademisi bidang agama Hindu. Hasil penelitian menunjukkan: Nilai yang terdapat meliputi nilai pendidikan teologi dalam bentuk ajaran ketuhanan dan pemujaan kepada Tri Purusa (Parama Siwa, Sada Siwa dan Siwa), dan nilai pendidikan kesehatan meliputi pengetahuan tentang berbagai macam penyakit, cara pengobatan, pengetahuan mantram usada dan sarana yang didasari atas konsep siwaistik melalui ajaran tantra. Selanjutnya konsep pengobatan tradisional usada yeh didasari oleh pemahaman susunan dan urutan dasaaksara, dalam bentuk pengobatan akan segala jenis penyakit menggunakan beberapa sarana yaitu sarana air, mantram, ramuan tetes, jamu, sembur, bedak, usug, sesayut, caru, daksina dan upakara lainnya termasuk usada yeh dapat diimplementasikan dengan digabungkan menggunakan segala jenis pohon kayu. Sebagai kesimpulan, nilai dan konsep pengobatan tradisional pada lontar usada yeh berpusat pada sarana air, mantram dan sarana yang berbahan pada ramuan alami serta upakara lainnya.
\end{abstract}

Kata Kunci: Nilai; Pengobatan Tradisional; Usada Yeh; Lontar 


\section{Pendahuluan}

Usada yeh pada hakekatnya merupakan lontar usada yang berisi tentang jenis penyakit, cara pengobatan dan sarana yang dipergunakan, dalam usada yeh disebutkan mengetahui susunan serta urutan dari dasaksara sebagai dasar utama menggunakan pengobatan usada tersebut. Usada yang terdapat pada lontar sebagai warisan budaya, warisan leluhur, sangat berharga dan sangat penting untuk dirawat, dijaga, dilestarikan, digali isinya karena banyak mengandung ilmu pengetahuan dan ajaran agama Hindu. Pengetahuan yang terdapat dalam usada juga dapat dipakai sebagai bahan analisis, panduan pelaksanaan dan tatanan hidup sehat masyarakat Hindu di Bali.

Lontar usada yeh memiliki konsep dan pengobatan tradisional yang memiliki kekhususan karena mengutamakan penguasaan konsep dasaaksara dengan menggunakan sarana air dan mantram dalam implementasinya, termasuk menggunakan beberapa ramuan yang bersumber dari bahan alam tumbuhan, batang, upakara dan lain sebagainya. Selama ini sistem pengobatan tradisional yang berkembang di masyarakat mengalami berbagai macam kendala sosio psikologis, hal ini disebabkan karena minimnya pengkajian terhadap berbagai naskah lontar usada dalam persfektif modern dan ilmiah. Masyarakat selama ini hanya mempercayakan pada seorang tokoh usada/pangusada termasuk balian sebagai pengobat tradisional bali saja, yang membaca dan mempelajari lontar untuk praktik dalam kehidupan sehari-hari. Perlu adanya pengkajian dan pengembangan dari berbagai macam lontar usada salah satunya melalui usada yeh akan memperkaya ilmu pengetahuan kesehatan dan pengobatan tradisional yang berkembang saat ini.

Dalam perspektif pendidikan dan sastra, keberadaan lontar usada yeh merupakan sumber pengetahuan yang mengandung nilai-nilai budaya, ilmu pengetahuan yang apabila digali akan banyak didapatkan manfaat bagi perkembangan ilmu pengetahuan, agama, dan ilmu pengetahuan kesehatan. Namun jika dilihat dari jenis tokoh usada/pangusada dan balian berdasarkan pengetahuan yang diperoleh terdapat empat yaitu a) balian ketakson yaitu keahlian yang disebabkan melalui taksu, b) balian kapican yaitu keahlian yang disebabkan benda bertuah, c) balian usada yaitu keahlian karena belajar dari lontar usada, guru waktra, dan sadar akan ilmu pengobatan, d) balian campuran yaitu karena pica dan mempelajari usada (Suardika, 2019). Sistem pengobatan tradisional yang berkembang di masyarakat oleh tokoh pengobatan tradisional akan lebih bermanfaat apabila dilengkapi dengan sumber pengetahuan yang berasal dari kajian lontar usada.

Lontar usada yang banyak tersebar di Bali menurut Nala secara umum merupakan hasil dari kreativitas dan pengetahuan orang Bali yang tidak terlepas dari ajaran agama Hindu (Suardiana, 2018). Pada masyarakat Bali, usada dikenal memiliki fungsi sebagai sumber pengetahuan dan sebagai alternatif dalam bidang penyembuhan penyakit. Pemahaman terhadap lontar jenis usada mulai dikenal dan diminati oleh masyarakat seiring pelestarian budaya dan kearifan lokal yang terus berkembang.

Secara teori keberadaan usada yeh pada masyarakat Bali masih dipercaya memberikan manfaat dan menyembuhkan orang sakit. Masyarakat percaya bahwa salah satu cara untuk menyembuhkan sakit yang diakibatkan oleh ketidakseimbangan dalam tubuh adalah dengan menggunakan pengobatan usada melalui praktisinya yaitu tokoh usada/pangusada dan balian. Manfaat dari pengobatan usada adalah mampu untuk melihat serta mengobati ketidakseimbangan tersebut, terutama dengan menggunakan praktisi dari pengobatan usada yaitu balian (Triyono, 2017). Pemanfaatan usada yeh melalui tokoh usada/pangusada dan balian akan lebih memberikan manfaat bagi masyarakat hindu di Bali.

Hasil penelitian yang dilakukan oleh Suardina (2018) ditemukan arti penting usada bagi masyarakat di Bali di tengah era global, masyarakat saat ini masih jarang memanfaatkan bahan obat herbal yang direkomendasikan dalam teks usada, pengetahuan pengobatan tradisional usada ini sangat tepat dikembangkan dalam menyambut era global, apabila para penekun 
bidang ilmu pernaskahan (filolog) mencurahkan perhatian pada naskah usada, dikemudian hari akan lahir dokter-dokter usada yang mampu membantu masyarakat dalam mengatasi penyakit dan berbagai masalah kesehatan lainnya.

Pemecahan masalah bidang kesehatan melalui pengobatan tradisional juga diuraikan oleh Tri sutrisna et al (2019) dalam penelitiannya dinyatakan bahwa pengobatan tradisional yang bersumber dari usada merupakan salah satu sumber dalam memecahkan masalah kesehatan. Pengobatan tradisional pada lontar sebagian meliputi jenis penyakit, ramuan pengobatan, bentuk sediaan dan cara penggunaan yang dignakan secara turun temurun oleh masyarakat.

Sementara dalam penelitiannya I Ketut Suardika (2019) menyatakan bahwa usada sebagai sumber pengetahuan pengobatan tradisional bali, konsep yang terdapat didalamnya untuk memecahkan berbagai masalah dalam bidang kesehatan. Dengan memahami konsep yang terdapat pada usada serta mampu memanfaatkan konsep usada pada berbagai bidang diantaranya bidang pencegahan, teknik pengobatan, rehabilitasi dan penelitian. Hal tersebut bermanfaat untuk mengembangkan ilmu pengetahuan dan teknologi di bidang kesehatan. Masyarakat sebagian besar masih percaya bahwa pengobatan menggunakan usada banyak memiliki manfaat diantaranya menyembuhkan orang sakit dan memelihara kesehatan. Keberadaan usada dan pengobatan tradisional tetap menjadi pilihan yang tidak dapat dikesampingkan begitu saja pada masyarakat di bali baik yang tinggal di desa maupun di kota.

Secara empiris di era pengetahuan dan teknologi perkembangan pengobatan medis semakin maju, namun masih banyak dari masyarakat yang tetap menggunakan pengobatan tradisional, pengobatan tradisional dipercaya mampu mengobati berbagai macam penyakit dengan resiko yang lebih kecil dan biaya yang murah, menurut asimo penggunaan pengobatan tradisional tidak terlepas dari ketidakpuasan terhadap pengobatan medis, hal ini juga terlihat pada masyarakat bali yang masih banyak menggunakan pengobatan tradisional (Samuel, 2017). Pengobatan tradisional Bali dengan menggunakan usada yeh telah cukup dikenal dan dipergunakan oleh tokoh usada/pangusada dan balian di Bali, namun belum dimanfaatkan dengan baik, selain itu pengobatan melalui usada khususnya pada usada yeh memerlukan pemahaman dan pengetahuan dasaaksara. Sehingga diperlukan pemahaman dan pengkajian terhadap lontar usada yeh.

Secara signifikansi penelitian ini menjadi sangat penting dengan adanya pengkajian terhadap usada yeh akan meningkatkan pemahaman dan penggunaan secara baik oleh masyarakat di Bali khususnya dalam pengobatan tradisional yang bersumber dari nilai dan konsep pengobatan lontar usada yeh.

\section{Metode}

Penelitian ini merupakan satu diantara beberapa permasalahan penelitian yang dikaji dari penelitian besar tentang usada yeh dan implikasinya bagi masyarakat Hindu di Bali. Penelitian yang dilakukan adalah penelitian kualitatif dengan menggunakan pendekatan etnomedisin. Pengumpulan data dilakukan selama empat bulan sejak Juli sampai Oktober 2021 pada beberapa tempat yaitu pada Pusat Dokumentasi dan Kebudayaan Bali, ITEKES Bali, dan Yayasan Tantra Nusantara. Dalam penelitian ini objek kajian yang diteliti adalah lontar usada yeh, dari sudut pandang nilai dan konsep pengobatan tradisional. Pengumpulan data dilakukan melalui analisis isi (content analysis) lontar usada yeh, dan selanjutnya dikembangkan melalui wawancara mendalam dengan tokoh usada/pangusada dan praktisi tantra yaitu Jero Ketut Sandika dari Yayasan Tantra Nusantara serta tokoh agama sekaligus akademisi yang memiliki kompetensi di bidang usada bali dan budaya agama Hindu khususnya mengenai usada yeh, kesehatan, dan budaya agama Hindu di Bali yaitu Dr. Putu Sabda Jayendra serta tokoh dan akademisi lainnya. Hasilnya diwujudkan menjadi tulisan untuk menggambarkan objek yang diteliti. 


\section{Hasil dan Pembahasan}

Usada pada hakekatnya merupakan pengetahuan tentang sistem pengobatan tradisional masyarakat Bali, yang dapat dijadikan pedoman dan konsep dalam memecahkan berbagai masalah pada bidang kesehatan. Penguasaan konsep usada tersebut dan memanfaatkannya dalam kerangka konseptual di bidang pencegahan, pengobatan, rehabilitasi serta penelitian berguna untuk mengembangkan ilmu pengetahuan dan teknologi di bidang kesehatan (Suardika, 2019).

Usada Bali yang termuat pada lontar sebagai salah satu sumber pengetahuan masyarakat Hindu di Bali tentang kesehatan dan penyembuhan mengandung banyak nilai agama Hindu. Lontar Usada Bali adalah manuskrip yang berisi nilai dan sistem pengobatan, bahan obat, dan cara pengobatan tradisonal yang memiliki arti dan posisi penting dalam khasanah pengobatan tradisonal Bali yang senantiasa dipelihara oleh masyarakat sebagai sebuah warisan luhur (Sanjaya \& Bhandesa, 2019). Usada Bali termuat pada lontar yang tersebar di berbagai daerah di Bali yang sebagian besar ada di UPTD Gedong Kertia Singaraja, Pusat Dokumentasi dan Kebudayaan Bali, Fakultas Bahasa dan Sastra Universitas Udayana, UNHI, UHN I Gusti Bagus Sugriwa, lontar usada juga banyak tersebar di berbagai Griya atau rumah tokoh usada serta di berbagai daerah yang ada di Bali. Lontar tersebut merupakan naskah tradisional yang banyak memuat ajaran dan nilai yang bersumber dari agama Hindu yang sebagian besar memuat ajaran tentang agama dan ketuhanan, sesana (kesusilaan), usada (pengobatan), wariga (Ilmu perbintangan), itihasa, babab (sejarah) dan lain sebagainya.

Usada yeh merupakan salah satu dari ratusan naskah daun lontar yang berisi terapi tradisional di Bali. Usada yeh berisi tentang jenis penyakit, cara pengobatan dan sarana yang dipergunakan untuk mengobati penyakit, dalam usada yeh disebutkan mengetahui susunan serta urutan dari dasaksara sebagai dasar menggunakan pengobatan usada tersebut. Usada yeh disambut baik oleh masyarakat Bali khususnya masyarakat yang bekerja sebagai praktisi medis Bali (tokoh usada/ pangusada dan balian).

Menurut hasil wawancara dengan narasumber Jero I Ketut Sandika pada lontar usada yeh, terdapat konsep teologi yang diuraikan pada bagian awal lontar sebagai berikut. "Om Sang Hyang Siwa Ring Siwadwara, Parama Siwa ring tungtunging rambut, Sada Siwa ring irengin netra, Siwa ring tungtunging irung, sah siwa ring tungtunging muka, Sang Hyang Kasiapa ring tungtunging lidah, angerapuh wisia sahananing wisia rapuh, denira Hyang Siwa, Sada Siwa, Parama Siwa, Siwa, Sah Siwa, Kasiapa, Om ang ang mang mang ang ung teka rapuh".

Mantra tersebut dapat diterjemahkan sebagai berikut "Om Sanghyang Siwa di ubunubun, Paramasiwa di ujung rambut, Sadasiwa di hitamnya mata, Siwa di ujung hidung, Sah (Siwatma) Siwa di ujung wajah, Sanghyang Kasiapa di ujung lidah, meleyapkan semua racun (penyakit) dan semua penyakit dilenyapkan, oleh beliau Sanghyang Siwa, Sadasiwa, Paramasiwa, Sahsiwa, Kasiapa, Om Ang Ang Mang Mang Ang Ung jadilah musnah”.

Berdasarkan uraian di atas dapat dimaknai kutipan mantram yang terdapat pada bagian awal lontar usada yeh dan merupakan intisari dari usada sari yang disebut sebagai usada bayu mengandung makna nilai pendidikan teologi dalam bentuk ajaran ketuhanan dan pemujaan kepada Tri Purusa (Parama Siwa, Sada Siwa dan Siwa). Pemujaan kepada Tuhan Yang Maha Esa, dalam manifestasinya sebagai Dewa (pemberi sinar) dan Bhatara (pelindung) adalah sebagai wujud pengetahuan tinggi dan mulia dari Sang Hyang Kasiapa untuk memohon perlindungan dan kesembuhan dari segala macam penyakit yang ada. Pada lontar usada yeh juga terdapat mantram yang digunakan untuk jenis penyakit tertentu. Serta makna caru yang dilakukan adalah untuk meningkatkan keharmonisan dan kesejahteraan semua mahluk hidup di dunia.

Sejalan dengan prinsip holografis, dasaksara bersemayam pada tubuh manusia (bhuana alit). Dalam tubuh manusia termanifestasi unsur aksara-aksara tertentu yang bergetar dan membentuk mandala, berpusat di inti hati tempat Sanghyang Suwung (Tuhan) bersthana 
sebagai Sanghyang Atma (Atman/roh). Memahami dan menggunakan serta mendayagunakan dasaaksara yang ada dalam tubuh manusia akan mampu mengoptimalkan kesadaran alami rohani manusia sehingga sakti dan waskita. Lebih dari pada itu, bagi yang mampu menyatukan semua aksara di tubuhnya dan memusatkannya pada Sanghyang Suwung di inti hatinya, ia akan menjadi manusia sempurna, yang disebut dengan moksa (Sandika, 2019).

Secara teologi dalam terminologi masyarakat Hindu Bali pada umumnya tidak ada ruang-ruang khusus tanpa kehadiran dari Tuhan, karena Tuhan hadir di mana-mana Vyapi Vyapaka Nirvikara (Silawati, 2019). Hal ini menandakan bahwa setiap kegiatan dalam kehidupan masyarakat Hindu termasuk dalam memperoleh kesehatan selalu melibatkan Tuhan untuk hadir dan memberikan anugrahnya. Karena diyakini pula bahwa Tuhan juga bersthana dalam diri manusia dalam bentuk atman (percikan suci dari Tuhan) sebagai jiwa dari semua mahluk hidup, atman juga dapat berfungsi sebagai aspek kesadaran dalam diri manusia yang mampu menggerakkan sthula sarira (badan jasmani manusia).

Berdasarkan konsep teologi kesehatan Hindu terdapat penggunaan simbol dewa-dewa yang tidak dapat dipisahkan dari tugas dan fungsi dewa yang dalam agama Hindu dalam bentuk linggih, genah, sthana (tempat kedudukan) baik di dalam badan manusia (bhuana alit atau mikrokosmos), maupun di alam raya (bhuana agung atau makrokosmos). Melalui kepercayaan kepada Tuhan dan manifestasinya, sebagai penganugrah kesehatan. Hal ini dapat memberikan manfaat memurnikan kesadaran jasmani dan memurnikan kesadaran rohani (Juniarta, 2019).

Lebih lanjut dapat kita lihat konsep teologi yang tertuang dalam lontar usada yeh merupakan konsep teologi siwaistik. Agama Hindu yang berkembang di Indonesia menurut Sura adalah paham Saiwasiddhanta yang awal mulanya berkembang di India Selatan. Akan tetapi dalam perkembangannya beradaptasi dengan kebudayaan setempat dan membentuk kebudayaan baru, yaitu apa yang disebut dengan kearifan lokal. Kearifan lokal dalam perkembangannya menjadi kekuatan filterisasi yang memiliki kemampuan untuk menyeleksi pengaruh segala jenis kebudayaan dari luar. Hal semacam ini yang menjadikan kebudayaan asli daerah tampak eksis pada tingkat dipermukaan. Artinya, agama Hindu yang datang dari India berinteraksi dengan kebudayaan asli daerah sehingga menjadikan agama Hindu di Indonesia mempunyai warna yang berbeda dengan induknya, India (Sudarsana, 2019). Hal ini menandakan bahwa konsep teologi siwaistik yang tertuang dan terkandung dalam lontar usada yeh, mengandung unsur magis, taksu, sebagai bagian dari kebudayaan Hindu yang tumbuh subur di Indonesia khususnya di Bali.

Diantara unsur yang dipergunakan dalam sistem pengobatan tradisional berbasis kearifan lokal bali, terdapat unsur magis yang paling penting dipergunakan yaitu terdapat mantra, rerajahan, dan wijaksara (Jirnaya, 2011). Hal ini dimaknai mantra, rerajahan dan wijaksara adalah ciri sistem pengobatan yang tidak bisa dilepaskan dalam sistem pengobatan tradisional bali, serta untuk pemusatan pikiran seorang tokoh usada/pangusada dan balian dalam menerapkan serta mengimplementasikan sistem pengobatan tradisionalnya.

Pengobatan Usada yeh lebih menekankan dengan menggunakan sarana air, mantra, banten/sesayut, caru dan berbagai jenis tanaman obat (Dinkes Provinsi Bali, 1982). Lontar yang serupa dengan Usada yeh juga ditemukan pada pusat dokumentasi budaya bali dalam bukunya berjudul alih aksara lontar tahun 1997 sebagai Usada Wwe. Usada Yeh menekankan penyembuhan dengan menggunakan sarana air dan mantram yang dipergunakan, penggunaan usada yeh juga dilengkapi dengan menggunakan akar, batang dan tumbuhan obat. Nilai pendidikan selanjutnya yang terdapat dalam lontar usada yeh adalah nilai pendidikan kesehatan meliputi pengetahuan tentang berbagai macam penyakit, ciri penyakit, cara pengobatan, pengetahuan mantram usada dan sarana yang didasari atas konsep siwaistik melalui ajaran tantra. Jenis penyakit yang banyak dipaparkan adalah jenis penyakit dalam. Diantaranya sakit mata, sakit perut, sakit kepala, sakit panas, jampi, keracunan, diare, muntaber, dan lain-lain. 
Berdasarkan konsep dan sistem pengobatan Ayurveda terdapat bentuk pengobatan menggunakan air yang oleh masyarakat Hindu di Bali dikenal dengan panglukatan. Air memiliki komponen yang mampu merespon apapun yang diucapkan oleh manusia sebagai sistem alaminya. Air yang sudah diberikan mantram atau kata-kata dan kalimat suci, partikel pada air berubah dan membentuk kristal tertata dan indah, demikian pula sebaliknya. Pengobatan usada dalam sistem pengobatan tradisional masyarakat Hindu di Bali secara umum bersumber pada Ayurveda. Ayurveda merupakan sumber dan sastra dalam agama Hindu yang banyak memuat ilmu tentang kehidupan manusia dan kesehatan serta keharmonisan. Ayurveda juga menggunakan sistem pengobatan tradisional naturalis dan banyak menggunakan sarana air sebagai sarana yang banyak digunakan dalam terapi pengobatannya. Usada adalah sub turunan sistem pengetahuan Ayurveda, yang mana Ayurveda adalah bagian dari pustaka agama Hindu (Yuliari, 2019).

Pengobatan tradisional Bali (usada) yang dikenalkan oleh para leluhur merupakan ilmu pengetahuan penyembuhan yang dijiwai oleh nilai-nilai agama Hindu. Usada adalah pengetahuan pengobatan tradisional Bali, sebagai sumber konsep untuk memecahkan masalah di bidang kesehatan. Penguasaan konsep usada tersebut dan memanfaatkannya dalam kerangka konseptual di bidang pencegahan, pengobatan, rehabilitasi serta penelitian berguna untuk mengembangkan ilmu pengetahuan dan teknologi di bidang kesehatan (Suardika, 2019).

Usada juga dapat dikatakan sebagai ilmu pengetahuan untuk menemukenali berbagai macam dan jenis penyakit, berbagai bahan obat, dan berbagai mantra dalam menyembuhkan penyakit. Peranan usada dalam kehidupan sehari-hari adalah dapat dijadikan sebagai sumber rujukan dalam menjaga kesehatan dan meningkatkan proses kesembuhan. Dalam konteks kesehatan khususnya pada keperawatan komplementer pengobatan tradisional termasuk usada digolongkan sebagai salah satu kelompok pengobatan alternatif, namun secara teoritis pengobatan usada dapat dijadikan sebagai pelengkap, pendukung dan sejalan dengan pengobatan konvensional. Hal ini dikarenakan konsep, nilai dan cara pengobatan dalam lontar usada bersumber dari pengetahuan dan ajaran agama Hindu yang dikembangkan berdasarkan kearifan lokal pendahulu masyarakat Hindu di Bali yang dilaksanakan secara turun temurun.

Pengetahuan dan penyembuhan dalam lontar usada dibagi menjadi dua bagian, yaitu Tutur (ajaran-ajaran dan tafsiran) dan Usada (peraturan, resep, dan obat-obatan). Setiap individu dapat membaca usada yang berkaitan dengan penyakit dan obat-obatan, berbeda dengan tutur yang untuk orang awam agak sulit untuk dipahami dan dibaca karena menggunakan istilah Sanskerta dan atau istilah Kawi, disamping itu terdapat keistimewaan pada aksara-aksara yang dipergunakan, adanya lambang dan istilah yang bersifat rahasia, yang dipergunakan oleh penulisnya untuk menyulitkan orang yang tidak biasa membaca dan mempergunakannya secara tidak benar. Tidak jarang terdapat bahwa sebuah lontar tentang pengetahuan pengobatan terdiri atas dua bagian yaitu bagian Usada dan bagian Tutur. Terdapat bahwa lontar yang sama judulnya, tetapi isinya berlainan atau kebalikannya (Sudiasta \& Suwidja, 1991). Pengobatan tradisional sebagai bagian penting yang banyak dipraktikan oleh masyarakat. menurut WHO adalah jumlah total pengetahuan, keterampilan, dan praktekpraktek yang berdasarkan teori, keyakinan, dan pengalaman masyarakat yang mempunyai adat dan budaya yang berbeda, baik dijelaskan atau tidak, digunakan dalam pemeliharaan kesehatan serta dalam pencegahan, diagnosa, perbaikan atau pengobatan penyakit secara fisik dan juga mental (Triyono, 2017).

Menurut Undang-Undang Nomor 36 Tahun 2009, pada pasal 59 menyatakan berdasarkan cara pengobatannya, pelayanan kesehatan tradisional terbagi menjadi (1) pelayanan kesehatan tradisional yang menggunakan keterampilan, dan (2) pelayanan kesehatan tradisional yang menggunakan ramuan. Jenis pengobatan tradisional yang terdapat di Indonesia sangat beragam, masing-masing daerah dan budaya memiliki sistem pengobatan tradisional yang bersumber dari kearifan lokal masyarakat dengan dijiwai oleh sistem keyakinan dan 
kepercayaan tertentu, keanekaragaman hayati yang terdapat pada masing-masing daerah juga menjadikan kekayaan dan keberagaman serta kebudayaan munculnya beragam produk budaya salah satunya adalah pengobatan tradisional. (Bagiastra, 2019).

Cara pengobatan dan menjaga kesehatan menurut usada bali ada berbagai cara yaitu apunin (diminyaki), menggunakan loloh (obat minum/ jamu), boreh (diparemi), oles (diolesi), pepeh atau tutuh (obat tetes melalui hidung), ses (menekan bagian yang sakit oleh bahan yang dipanasi), simbuh (sembur), urap (obat oles), usug (oles dengan berulang kali), tirta, panglukatan, natab banten (upakara) dan lain sebagainya. Pemanfaatan usada untuk pengobatan beberapa penyakit yang sering digunakan oleh pangusadha di bali tercantum dalam beberapa lontar usada diantaranya lontar usada bali dalem jawi, usada taru pramana, usada cukil daki, usada bodha kecapi, usada rukmini tattwa dan usada yeh. Dalam usada yeh cara pengobatan yang dilakukan adalah dalam bentuk tetes, jamu, sembur dan boreh.

Usada yeh menekankan pengobatan dengan menggunakan sarana air dan terdapat mantram serta dapat digabungkan dengan segala jenis tanaman obat namun untuk mengimplementasikan usada yeh seorang pangusadha wajib mengetahui susunan dan urutan dari dasaaksara. Berdasarkan hasil wawancara dengan Jero Ketut Sandika seorang tokoh usada/pangusada dan tantra mengemukakan bahwa usada yang ada di bali tidak terlepas dari konsep ajaran tantra. Tantra memiliki cakupan yang sangat luas, dikenal senbagai ilmu holistik dan rahasa jnana, mengimplementasikan usada dan tantra terdapat tatanan dan etika. Usada yeh sangat dekat dengan tantra, dalam usada yeh terdapat berbagai sarana dan bahan obat serta menggunakan mantram dalam pelaksanaannya. Dalam konsep ajaran tantra (tan matra, semua tanpa batas, ujung tanpa akhir, dan dasar dari segala ilmu pengetahuan dan spiritual), pada usada yeh juga terdapat istilah mecaru, pemujaan sakti, identik dengan barong, tantra juga mengandung makna magis, energi, gaib, sesuatu yang mempesona. Konsep pengobatan yang terdapat pada lontar usada yeh sangat identik dan dekat dengan konsep tantra tersebut. Menggunakan caru, mantram, dan berbagai ramuan yang berbahan dari akar dan kayu tertentu.

Lebih lanjut Jero Ketut Sandika juga memaparkan penggunaan usada yeh perlu memahami konsep aksara dengan baik sebagai bagian dan ciri khas tantra nusantara. Pengetahuan spiritual terkait aksara dalam agama hindu terdapat dalam bentuk tattwa, kadyatmikan, usada yang bernuansa tantrik. Ciri khas tersebut dalam bentuk aksara. Aksara diibaratkan kode atau energi, aksara juga disebut sebagai rumah energi. Pemanfaatan dasaaksara dalam usada yeh merupakan wujud nyata implementasi teori tentang adanya energi dalam bentuk aksara. Aksara berasal dari kata " $A$ " artinya tidak dan "Ksara" artinya termusnahkan, ini berarti aksara mengandung makna sesuatu yang tidak termusnahkan atau dikenal sebagai energi (bahkan dalam hukum kekekalan energi oleh Newton, juga telah jelas secara ilmiah tidak ada energi yang hilang, yang ada adalah energi yang mengalami perubahan wujud). Bentuk aksara juga beragam ada dalam bentuk kerakah, modre, kekereh dan lain-lain.

Lebih lanjut diuraikan bahwa untuk menjalankan usada yeh harus mengikuti sesananing usada dan harus memahami aksara (tatas nawang incep aksara lan sastra). Dalam usada juga ditekankan bahwa penyakit itu berasal dari pikiran, bahkan $99 \%$ penyakit itu muncul dan bermula dari pikiran maka dari itu mengendalikan, menyucikan dan menjaga pikiran untuk selalu baik dan sehat menjadi sangat penting dalam konsep pengobatan tradisional atau usada itu sendiri. Karena bermula dari pikiran maka dalam konsep usada sakit dan obat ada dalam diri. Lingkungan, bahan, ramuan, jamu serta upacara dan upakara yang dilakukan sebagai pengingat, sebagai energi yang diharmonisasikan sehingga berpengaruh bagi kesehatan seseorang.

Konsep pengobatan yang terdapat dalam usada yeh yaitu berbentuk penglukatan. Penglukatan merupakan proses penyucian diri, menyeimbangkan energi destruktif menggunakan sarana air. Air merupakan pengantar energi yang paling cepat diawali dari tirta, aksara, dasa aksara dan dasa bayu. 
Berdasarkan hasil wawancara dengan narasumber Dr. Putu Sabda Jayendra, seorang akademisi dan dosen bidang agama Hindu dan budaya mengemukakan konsep pengobatan yang termuat dalam usada memiliki makna spiritual dan makna etnomedisin. Untuk memahami dengan baik dan benar tentang usada dan konsep pengobatan tradisional yang tercantum juga diperlukan pemahaman tentang semiotika dari sastra dan lontar usada yang ada termasuk usada yeh. Secara umum selain etika dan tatanan yang perlu dijaga bahwa pendahulu dan tetua leluhur di Bali memuat usada dalam sebuah lontar penuh dengan makna dan kerahasiaan, tujuannya dalah agar tidak disalahartikan, pemahaman akan teknik dan ritual pengobatan. Semua itu dikenal sebagai kode petunjuk dengan tujuan mencapai keharmonisan dan keseimbangan.

Tabel 1. Berbagai jenis penyakit dan teknik pengobatan tradisional menurut lontar usada yeh:

\begin{tabular}{|c|c|c|c|c|}
\hline No & $\begin{array}{c}\text { Jenis } \\
\text { Penyakit }\end{array}$ & $\begin{array}{c}\text { Sarana yang } \\
\text { dipergunakan }\end{array}$ & $\begin{array}{c}\text { Cara } \\
\text { pengobatan/penggunaan }\end{array}$ & Mantram \\
\hline \multirow[t]{5}{*}{1} & \multirow[t]{5}{*}{ Panas } & \multirow[t]{5}{*}{ Air } & Sembur & Ong mang hang \\
\hline & & & Sirat & Ung mang ang ang \\
\hline & & & Jamu/diminum & ong mang hang \\
\hline & & & Tetes mata & uh mang ih \\
\hline & & & Kompres & ong ih ah \\
\hline \multirow[t]{3}{*}{2} & \multirow[t]{3}{*}{ Sakit Mata } & \multirow[t]{3}{*}{ Air } & Sirat & om taya ah ih \\
\hline & & & Sembur & Om taya I ah \\
\hline & & & Usapkan/raupan & Om Taya ing \\
\hline \multirow[t]{3}{*}{3} & \multirow[t]{3}{*}{ Sakit Perut } & \multirow[t]{3}{*}{ Air } & Jamu/diminum & Mang mang ung ayang \\
\hline & & & Sirat & Om ing mang ang \\
\hline & & & Raup & Om taya ah \\
\hline \multirow[t]{3}{*}{4} & \multirow[t]{3}{*}{ Sakit kepala } & \multirow[t]{3}{*}{ Air } & Jamu/diminum & Om mang ah \\
\hline & & & Sirat & Om mang ih \\
\hline & & & Usapkan/raupan & om ang ung mang ing \\
\hline \multirow[t]{2}{*}{5} & \multirow[t]{2}{*}{ Jampi } & \multirow[t]{2}{*}{ Air } & Sirat & ong ih ah \\
\hline & & & Jamu & om ah ih \\
\hline 6 & $\begin{array}{l}\text { Sakti } \\
\text { persendian }\end{array}$ & Air & sirat & $\begin{array}{l}\text { ayang siang om, om } \\
\text { mang ang siang }\end{array}$ \\
\hline 7 & Cekutan & $\begin{array}{l}\text { Air, Pinang } \\
\text { muda, dan air } \\
\text { dari } \\
\text { kasimbukan }\end{array}$ & Jamu & Om nama swaha \\
\hline 8 & $\begin{array}{l}\text { Obat } \\
\text { penawar } \\
\text { ludra kuta }\end{array}$ & $\begin{array}{l}\text { Tempurung } \\
\text { kelapa, lima } \\
\text { macam bunga, } \\
\text { air }\end{array}$ & $\begin{array}{l}\text { sarananya air taruh di } \\
\text { dalam tempurung kelapa, } \\
\text { diisi } 5 \text { macam bunga }\end{array}$ & Om herang ing \\
\hline 9 & $\begin{array}{l}\text { Obat Kunda } \\
\text { Wijaya }\end{array}$ & $\begin{array}{l}\text { Tempurung } \\
\text { kelapa, bunga } \\
\text { merah, air }\end{array}$ & $\begin{array}{l}\text { sarananya air taruh di } \\
\text { tempurung kelapa (sibuh) } \\
\text { serta bunga berwarna } \\
\text { merah }\end{array}$ & $\begin{array}{l}\text { Om ang ung mang ah ih, } \\
\text { om ang ung mang ih }\end{array}$ \\
\hline 10 & $\begin{array}{l}\text { Obat } \\
\text { penawar } \\
\text { Mpu } \\
\text { Baradah }\end{array}$ & $\begin{array}{l}\text { Tempurung } \\
\text { kelapa hitam, } \\
\text { bunga putih, } \\
\text { air }\end{array}$ & $\begin{array}{l}\text { air taruh dalam tempurung } \\
\text { kelapa yang berwarna } \\
\text { hitam (sibuh) serta berisi } \\
\text { bunga putih }\end{array}$ & $\begin{array}{l}\text { Om batara Mpu } \\
\text { Baradah, anempur } \\
\text { gunane I calonarang, } \\
\text { apan aku sang Empu } \\
\text { Baradah sakti, angurip } \\
\text { wong manusa yeki, om } \\
\text { sidirastu urip, teka urip, }\end{array}$ \\
\hline
\end{tabular}




\begin{tabular}{|l|l|l|l|l|}
\hline 11 & $\begin{array}{l}\text { Penawar } \\
\text { Sang Hyang } \\
\text { Tunggal }\end{array}$ & $\begin{array}{l}\text { Tempurung } \\
\text { kelapa, bunga } \\
\text { putih, air }\end{array}$ & $\begin{array}{l}\text { air taruh dalam tempurung } \\
\text { kelapa, bunga putih }\end{array}$ & $\begin{array}{l}\text { Ong ang ung mang ing } \\
\text { ingkeng }\end{array}$ \\
\hline 12 & $\begin{array}{l}\text { Sang Hyang } \\
\text { Dharma }\end{array}$ & $\begin{array}{l}\text { Tempurung } \\
\text { kelapa hitam } \\
\text { dan bungan } \\
\text { warna hitam }\end{array}$ & $\begin{array}{l}\text { sarana air taruh dalam } \\
\text { tempurung kelapa hitam, } \\
\text { bunga juga hitam }\end{array}$ & Om ung ung ing ih \\
\hline 13 & Sutasoma & $\begin{array}{l}\text { Tempurung } \\
\text { kelapa, bunga } \\
\text { putih, air }\end{array}$ & $\begin{array}{l}\text { sarananya air yang jernih, } \\
\text { suci, bersih, taruh dalam } \\
\text { tempurung kelapa serta } \\
\text { bunga putih }\end{array}$ & Pang ung ang mang ih \\
\hline 14 & Wisnu Murti & $\begin{array}{l}\text { Air mumbul, } \\
\text { tempurung } \\
\text { kelapa, bunga } \\
\text { wari } \\
\text { bunga dan } \\
\text { sudamala }\end{array}$ & $\begin{array}{l}\text { air mumbul taruh di dalam } \\
\text { tempurung kelapa, serta } \\
\text { bunga wari merah susun, } \\
\text { bungan sudamala }\end{array}$ & om ih ung aya mang ih \\
\hline
\end{tabular}

Pengetahuan tentang sistem pengobatan tradisional merupakan sebuah hasil kekayaan intelektual para generasi pendahulu yang layak dihargai dan diperhatikan karena terbukti telah mampu berperan menjaga dan mengatasi kesehatan para leluhur kita. Pada masa lampau kekayaan intelektual pengetahuan tentang sistem pengobatan tradisional menjadi milik masyarakat, menjadi memori bersama, bilamana ada yang membutuhkan seluruh warga saling membantu informasi, menunjukkan dan mencarikan bahan, hingga proses pembuatan sehingga pengetahuan tersebut bisa tersebar luas dan terwariskan secara alamiah kepada warga masyarakat antar generasi (Mumfangati, 2021). Adanya pemahaman melalui sumber lontar itu sendiri akan melengkapi sistem pengobatan yang sudah ada secara turun temurun.

Menunit lontar usada, penyakit ada tiga jenis, yakni penyakit panes (panas), nyem (dingin), dan sebaa (panas-dingin). Begitu halnya dengan obat dalam usada ada tiga macan yaitu obat yang berkhasiat anget (hangat), tis (sejuk) dan dumelada (sedang). Untuk melaksanakan semua aktivitas ini Bhatara Siwa memberikan wewenang kepada Bhatara Brahma, Wisnu, dan Iswara. Penyakit panes dan obat yang berkhasiat anget menjadi tugas dan kewenangan Batara Brahma. Batara Wisnu bertugas untuk mengadakan penyakit nyem dan obat yang berkhasiat tis. Batara Iswara mengadakan penyakit sebaa dan bahan obat yang berkhasiat dumelada (Ardiyasa, 2021)

Pemahaman yang baik tentang makna semiotika dalam sastra dan lontar yang banyak berkembang di Bali juga sebagai bagian dalam menggali nilai dan makna yang terkandung di dalam usada maupun lontar yang ada. Nilai pendidikan yang ada merupakan respon terhadap lingkungan sehingga terwujud dalam bentuk nilai, etika dan upacara. Pada aspek etika sakit merupakan bagian dari karma dan atas kehendak sang pencipta, sakit juga bagian dari introspeksi diri (mulat sarira) dan tidak menyalahkan orang lain atau keadaan. Dari sudut pandang upacara yang terdapat pada lontar usada yeh dapat dimaknai sebagai petunjuk yang harus diupayakan menyadarkan manusia pada konsep keseimbangan dan keseimbangan sebagai tujuan.

\section{Kesimpulan}

Berdasarkan hasil dan pembahasan di atas dapat ditarik kesimpulan bahwa terdapat nilai yang terkandung dalam lontar usada yeh meliputi nilai pendidikan teologi dalam bentuk ajaran ketuhanan dan pemujaan kepada Tri Purusa (Parama Siwa, Sada Siwa dan Siwa), dan 
nilai pendidikan kesehatan meliputi pengetahuan tentang berbagai macam penyakit, cara pengobatan, pengetahuan mantram usada dan sarana yang didasari atas konsep siwaistik melalui ajaran tantra. Konsep pengobatan tradisional usada yeh didasari oleh pemahaman susunan dan urutan dasaaksara, dalam bentuk pengobatan akan segala jenis penyakit menggunakan beberapa sarana yaitu sarana air, mantram, ramuan tetes, jamu, sembur, bedak, usug, sesayut, caru, daksina dan upakara lainnya termasuk usada yeh dapat diimplementasikan dengan digabungkan menggunakan segala jenis pohon kayu.

Artikel ini memberikan kontribusi dalam bentuk nilai dan konsep pengobatan tradisional berdasarkan usada bali khususnya menurut lontar usada yeh yang banyak mengandung nilai filosofis ketuhanan dan sangat identik dengan nuansa tantrik dalam bentuk mantra, yantra, aksara dan mudra yang keseluruhan itu merupakan tantra. Penelitian ini merupakan penelitian awal tentang nilai dan konsep pengobatan tradisional dalam usada yeh, sehingga perlu dikembangkan dan dapat dilakukan penelitian lanjutan dalam bentuk penelitian pengembangan terkait teknik, bahan dan ramuan tradisional yang digunakan, termasuk pengembangan implikasi religiusitas, spiritualitas dan budaya pada masyarakat Hindu di Bali dengan adanya usada yeh yang banyak mengandung ajaran agama Hindu dan spiritualitas.

\section{Daftar Pustaka}

Ardiyasa, I. N. S. (2021). Ala Ayuning Dewasa dalam Usada Bali. Proseding Mistisisme Nusantara Brahma Widya. STAHN Mpu Kuturan Singaraja.

Bagiastra, I. N., \& Sudantra, I. K. (2019). Bali Dalam Pengembangan Pengobatan Tradisional Komplementer (Kajian Yuridis Peraturan Menteri Kesehatan Republik Indonesia Nomor 15 Tahun 2018 Tentang Penyelenggaraan Pelayanan Kesehatan Tradisional Komplementer). Jurnal Penelitian dan Pengembangan Sains dan Humaniora, 2(2), 8897.

Kantor Dokumentasi Budaya Bali. (1997). Alih Aksara Lontar Tahun 1997 Usada Wwe. Pemerintah Propinsi Daerah Tingkat I Bali, Denpasar. 58 hal.

Jirnaya. (2011) Lontar Usada Buduh: Sebuah Penanganan dan Pengobatan Tradisional Sakit Gila Berbasis Kearifan Lokal Bali. Prodi Sastra Jawa Kuno, Fakultas Ilmu Budaya Universitas Udayana.

Juniartha, M. G. (2019). Teologi Kesehatan Hindu Dalam Meditasi. Widya Genitri: Jurnal Ilmiah Pendidikan, Agama Dan Kebudayaan Hindu, 10(2), 86-107.

Mardawa, I. M. D., Sudarsana, I. K., \& Mahardika, I. A. W. (2019). Penggunaan Banten Daun Di Pura Dadia Alangkajeng Di Kelurahan Lelateng Kabupaten Jembrana (Kajian Nilai Pendidikan Agama Hindu). Jurnal Penelitian Agama Hindu, 3(4), 281-285.

Mumfangati, T. (2021). Usada Jawi: Pengobatan Tradisional Jawa Untuk Bayi Dan AnakAnak Dalam Serat Primbon Racikan Jampi Jawi Jilid I. BPNB DIY.

Proyek Penyalinan/Percetakan Lontar Usada. (1982). Usada yeh. Dinas Kesehatan Propinsi Daerah Tingkat I Bali. Bali. 25 hal.

Sandika, I Ketut. (2019). Tantra: Ilmu Kuno Nusantara. Javanica.

Suardika, I. K. (2019, September). Pengobatan Tradisional Usada Dan Balian Budaya Bali (Kajian Ilmu Sosial Budaya). In Prosiding Seminar Nasional (p. 53)

Suardiana, I. W. Naskah Pengobatan "Usada" di Bali dan Problematika Pemurnian Teks. Jurnal Kajian Bali (Journal of Bali Studies), 8(2), 1-14.

Sutrisna, I. N. G. T., Widyastuti, N. L. G., \& Cahyadi, K. D. (2019). Kajian Pengobatan Tradisional Cacar Menurut Terjemahan Lontar Usada Kacacar. Jurnal Riset Kefarmasian Indonesia, 1(1), 41-55.

Suatama, I. B. (2019). Masa Depan Usada Bali Dalam Wacana Modernitas. Widya Kesehatan, $1(2), 1-10$. 
Sanjaya, D. A., \& Bhandesa, A. M. (2019). Studi Eksplorasi Pengobatan Pada Usada Pemunah Cetik Kerikan Gangsa. Jurnal Penelitian Agama Hindu, 3(2), 144-148.

Silawati, Ni Wayan. (2019). Banten Pulagembal dalam Upacara Telu Bulanan di Desa Pakraman Serongga, Kecamatan Kerambitan Kapupaten Tabanan (Kajian Teologi Hindu). [Desertasi]. Denpasar: Program Pascasarjana IHDN Denpasar

Suatama, I. B. (2021). Usada Bali Modern. Yogyakarta: AG Litera Publishing

Suatama, I. B. (2019). Multikulturalisme Usada Bali. Widya Kesehatan, 1(1), 11-17.

Sudiasta, I. G. B., \& Suwidja, I. K. (1991). Terjemahan dan Kajian Usada Tenung Tanya Lara. Direktorat Jenderal Kebudayaan.

Triyono, S. D. K., \& Herdiyanto, Y. K. (2017). Konsep Sehat Dan Sakit Pada Individu Dengan Urolithiasis (Kencing Batu) Di Kabupaten Klungkung, Bali. Jurnal Psikologi Udayana, 4(2), 263-276.

Yuliari, S. A. M. (2019). Panglukatan Sapta Gangga Perspektif Usada Bali. Vidya Wertta: Media Komunikasi Universitas Hindu Indonesia, 2(2), 178-191. 